\title{
$\left[{ }^{3} \mathrm{H}\right]$-idazoxan binds with high affinity to two sites on hamster adipocytes: an $\alpha_{2}$-adrenoceptor and a non-adrenoceptor site
}

\author{
A.C. MacKinnon, C.M. Brown, M. Spedding \& ${ }^{1}$ A.T. Kilpatrick \\ Department of Pharmacology, Syntex Research Centre, Heriot-Watt University Research Park, Riccarton, \\ Edinburgh EH14 4AP
}

$1\left[{ }^{3} \mathrm{H}\right]$-idazoxan labels a single population of high affinity sites $\left(K_{\mathrm{d}} 2.26 \pm 0.02 \mathrm{nM} ; B_{\max } 372\right.$ $\pm 25 \mathrm{fmol} \mathrm{mg} \mathrm{m}^{-1}$ protein) in hamster adipocyte membranes. In the presence of $1 \mu \mathrm{M}$ yohimbine to preclude binding to $\alpha_{2}$-adrenoceptors, the density of $\left[{ }^{3} \mathrm{H}\right]$-idazoxan binding sites was reduced $\left(287 \pm 18 \mathrm{fmol} \mathrm{mg}^{-1}\right.$ protein) without an apparent decrease in the affinity $\left(K_{\mathrm{d}} 2.19 \pm 0.24 \mathrm{nM}\right)$ of the radioligand.

2 Displacement studies indicate that $\alpha$-adrenoceptor ligands with an imidazoline side chain completely inhibit $\left[{ }^{3} \mathrm{H}\right]$-idazoxan binding to hamster adipocyte membranes; in contrast, the $\alpha_{2}$-adrenoceptor antagonists yohimbine, rauwolscine, BDF 6143 and phentolamine inhibited only $20-30 \%$ of the specific binding with affinity values consistent with an interaction at $\alpha_{2}$-adrenoceptors.

3 The low potency of noradrenaline and adrenaline in displacing $\left[{ }^{3} \mathrm{H}\right]$-idazoxan binding to the second site on hamster adipocyte membranes indicates that it is unlikely that this site is a type of adrenoceptor.

4 These results suggests that $\left[{ }^{3} \mathrm{H}\right]$-idazoxan binds with high affinity to two sites in hamster adipocytes: an $\alpha_{2}$-adrenoceptor and a non-adrenoceptor imidazoline site.

\section{Introduction}

Catecholamine-induced lipolysis from adipocytes isolated from white fat in man (Burns et al., 1971), dog (Berlan \& Dang Tran, 1978) and hamster (Hittelman et al., 1973; Giudicelli et al., 1977) is mediated through a stimulatory $\beta$-adrenoceptor and an inhibitory $\alpha$-adrenoceptor. Studies indicate that $\alpha_{1}$ - and $\alpha_{2}$-adrenoceptors exist in hamster (GarciaSainz et al., 1980; Pecquery \& Giudicelli, 1980) and human (Fain \& García-Sainz, 1983) fat cells. The antilipolytic effects of $\alpha$-adrenoceptor agonists in hamster (Curtis-Prior \& Tan, 1984; Tan \& CurtisPrior, 1984) and man (Berlan \& Lafontan, 1980; Lafontan \& Berlan, 1980; Curtis-Prior \& Tan, 1984) are through the predominant $\alpha_{2}$-adrenoceptor.

The adipocyte is considered a suitable tissue to study the potency and selectivity of drugs that inter-

\footnotetext{
1 Author for correspondence.
}

act with $\alpha_{2}$-adrenoceptors (Huerta-Bahena et al., 1983). The $\alpha_{2}$-adrenoceptor present on human adipocytes is labelled with high affinity by $\left[{ }^{3} \mathrm{H}\right]$-clonidine, $\left[{ }^{3} \mathrm{H}\right]$-yohimbine and $\left[{ }^{3} \mathrm{H}\right]$-rauwolscine (Tharp et al., 1981; Berlan \& Lafontan, 1982; Lafontan et al., 1983; Richelsen \& Pedersen, 1985). $\left[{ }^{3} \mathrm{H}\right]$-clonidine binds with high affinity to hamster adipocyte membranes (Villeneuve et al., 1985; Taouis et al., 1986) whereas the labelling of $\alpha_{2}$-adrenoceptors by $\left[{ }^{3} \mathbf{H}\right]$-yohimbine has proved difficult to demonstrate (Villeneuve et al., 1985; Lafontan et al., 1985). Yohimbine, rauwolscine and idazoxan reverse clonidine-induced inhibition of lipolysis in hamster fat cells (Tan \& Curtis-Prior, 1983). The $\alpha_{2}$-adrenoceptor nature of the reversal is based upon rank order potency and not on receptor affinity.

In this study, we have examined the binding of $\left[{ }^{3} \mathrm{H}\right]$-idazoxan to hamster fat cells and compared its 
displacement by adrenaline, noradrenaline and a number of imidazoline and non-imidazoline $\alpha$ adrenoceptor ligands. We show that $\left[{ }^{3} \mathrm{H}\right]$-idazoxan, in addition to being a potent $\alpha_{2}$-adrenoceptor antagonist (Chapleo et al., 1981), labels an imidazoline binding site on hamster adipocytes, with high affinity.

\section{Methods}

\section{Preparation of adipocyte membranes}

Golden male hamsters (2-3 months old; weight range, $100-150 \mathrm{~g}$ ) were killed by cervical dislocation and the white adipose tissue carefully removed. Hamster adipocytes from epididymal fat were isolated essentially as described by Rodbell (1964) with minor modification with regard to the level of collagenase used in the digestion process. Adipocyte tissue $(8-10 \mathrm{~g}$ per animal) was minced finely and digested with crude collagenase $\left(1 \mathrm{mg} \mathrm{ml}^{-1}\right)$ in Krebs-Ringer bicarbonate buffer $(5 \% \mathrm{w} / \mathrm{v})$ containing $3.5 \%(\mathrm{w} / \mathrm{v})$ fatty acid deficient bovine serum albumin and $1 \mathrm{~mm} \mathrm{CaCl}$ for $20 \mathrm{~min}$ at $37^{\circ} \mathrm{C}$. During the digestion, the minced tissue was shaken vigorously approximately every $5 \mathrm{~min}$ by hand. The suspension containing the adipocytes was filtered through three layers of muslin and centrifuged at $400 \mathrm{~g}$ for $1 \mathrm{~min}$ at room temperature. The infranatant was removed by aspiration and the cells washed three times with Krebs-Ringer bicarbonate buffer to remove the collagenase. Isolated adipocytes were suspended in 10 vol. lysing medium $(5 \mathrm{mM}$ Tris $\mathrm{HCl}$, pH 7.4 containing $0.5 \mathrm{~mm}$ EDTA) and centrifuged at $400 \mathrm{~g}$ for $1 \mathrm{~min}$ at room temperature. The membrane fraction was collected and the unbroken cells lysed by a further two washes in the $5 \mathrm{~mm}$ Tris $\mathrm{HCl}$ buffer. The membrane fractions were pooled and centrifuged at $30,000 \mathrm{~g}$ for $15 \mathrm{~min}$ at $4^{\circ} \mathrm{C}$. The final pellet was suspended in $50 \mathrm{mM}$ Tris $\mathrm{HCl}$ buffer $\mathrm{pH} 7.4$ containing $10 \mathrm{mM} \mathrm{MgCl}_{2}$ and used immediately for ligand binding or stored for not more than 7 days under liquid nitrogen.

Male Sprague-Dawley rats $(180-200 g)$ were stunned, decapitated and the cerebral cortex dissected from the other brain regions over ice. Tissues were homogenized in 20 volumes of $50 \mathrm{~mm}$ Tris $\mathrm{HCl}$, $5 \mathrm{~mm}$ EDTA, pH 7.4 with a polytron PT 10 tissue disruptor (setting 10;2 $\times 10$ s bursts). The homogenate was centrifuged at $48,000 \mathrm{~g}$ for $15 \mathrm{~min}$ at $4^{\circ} \mathrm{C}$. The supernatant was discarded and the pellet resuspended in the original volume of assay buffer ( $50 \mathrm{~mm}$ Tris $\mathrm{HCl}, 0.5 \mathrm{~mm}$ EDTA, pH 7.4). Membranes were washed twice by repeated centrifugation at $48,000 \mathrm{~g}$ for $15 \mathrm{~min}$ at $4^{\circ} \mathrm{C}$. The final pellet was resuspended in assay buffer at an approximate protein level of $1 \mathrm{mg} \mathrm{ml}^{-1}$. Membranes were stored under liquid nitrogen until used in the binding assay.

\section{$\left[{ }^{3} \mathrm{H}\right]$-idazoxan binding}

Saturation experiments Adipocyte membranes (250-300 $\mu \mathrm{g}$ protein) and nine concentrations of $\left[{ }^{3} \mathrm{H}\right]$-idazoxan over the range $0.1-12 \mathrm{nM}$ were incubated to equilibrium in $50 \mathrm{~mm}$ Tris $\mathrm{HCl}$ buffer, $\mathrm{pH}$ 7.4 containing $10 \mathrm{mM} \mathrm{MgCl}_{2}$. Saturation studies were performed in the absence of yohimbine to determine the total density of binding sites or in the presence of $1 \mu \mathrm{M}$ yohimbine to preclude $\left[{ }^{3} \mathrm{H}\right]$-idazoxan binding to $\alpha_{2}$-adrenoceptors. Incubations were carried out for $30 \mathrm{~min}$ at $25^{\circ} \mathrm{C}$ in a final volume of $0.5 \mathrm{ml}$. Bound ligand was separated from free by vacuum filtration over GF/B filters on a Brandell cell harvester. The filters were washed twice for $10 \mathrm{~s}$ with incubation buffer and the bound radioactivity determined by liquid scintillation counting. Nonspecific binding at each free ligand concentration was determined in the presence of $1 \mathrm{~mm}$ phentolamine. Preliminary studies indicated that the imidazolines, cirazoline and naphazoline displaced non-specific $\left[{ }^{3} \mathrm{H}\right]$-idazoxan binding when defined by $10 \mu \mathrm{M}$ phentolamine, a concentration often used in $\alpha_{2}$-adrenoceptor binding studies. The level of nonspecific binding obtained with cirazoline and naphazoline was similar to the level obtained with $1 \mathrm{~mm}$ phentolamine.

Equilibrium binding parameters $\left(K_{\mathrm{d}}\right.$ and $\left.B_{\max }\right)$ were obtained by the iterative non-linear least square curve fitting programme 'ligand' (Munson \& Rodbard, 1980).

\section{Competition experiments}

$\left[{ }^{3} \mathrm{H}\right]$-idazoxan binding to hamster adipocytes Competition experiments in hamster adipocytes, were carried out in $50 \mathrm{~mm}$ Tris $\mathrm{HCl}$ buffer, $\mathrm{pH} 7.4$ containing $10 \mathrm{mM} \mathrm{MgCl}_{2}, 1.5 \mathrm{nM}\left[{ }^{3} \mathrm{H}\right]$-idazoxan and various drugs over the concentration range $10^{-3}$ to $10^{-12} \mathrm{M}$ in a final volume of $0.5 \mathrm{ml}$. Conditions for the competition assays were identical to those described for the saturation experiments. Nonspecific binding was defined by $1 \mathrm{mM}$ phentolamine and represented approximately $25 \%$ of total binding. Each determination was carried out in duplicate. Inhibition of specific binding of $\left[{ }^{3} \mathrm{H}\right]$-idazoxan by the drug was analysed to estimate the $\mathrm{IC}_{50}$ (concentration of drug displacing $50 \%$ of specific binding). The inhibitory constant $\left(K_{\mathfrak{i}}\right)$ was calculated from the $I_{50}$ by the equation of Cheng $\&$ Prusoff (1973).

$\left[{ }^{3} \mathrm{H}\right]$-idazoxan binding to rat cortical $\alpha_{2}$ adrenoceptors The displacement of $\left[{ }^{3} \mathrm{H}\right]$-idazoxan 
from $\alpha_{2}$-adrenoceptors in rat cortical membranes $(100-200 \mu \mathrm{g}$ protein) was carried out in $50 \mathrm{~mm}$ Tris $\mathrm{HCl}$ buffer, pH 7.4 containing $0.5 \mathrm{~mm}$ EDTA. Binding conditions were as previously described for hamster adipocyte membranes. Under these conditions, no evidence was obtained for $\left[{ }^{3} \mathrm{H}\right]$-idazoxan at a free ligand concentration of $1.5 \mathrm{nM}$, binding to an imidazoline site in rat cortex. Non-specific binding was defined by $10 \mu \mathrm{M}$ phentolamine and represented approximately $35 \%$ of total binding.

Protein level was determined by the method of Lowry et al. (1951) with bovine serum albumin used as the protein standard.

\section{Computer analysis of displacement curves}

Binding isotherms from displacement studies were analysed by a non-linear least square parametric curve fitting programme capable of fitting to a single or two site model. The programme provided a sum of square error for a single or two site model. The single site and two site models for each isotherm were compared using the differential $F$ value defined by the following equation:

$$
F=\frac{\left(\mathrm{SS}_{1}-\mathrm{SS}_{2}\right) /\left(\mathrm{df}_{1}-\mathrm{df}_{2}\right)}{\mathrm{SS}_{2} /\left(\mathrm{df}_{2}\right)}
$$

where $\mathrm{SS}_{1}$ is the sum of squares error for the single site, $\mathrm{SS}_{2}$ is the sum of squares error for the two site model, $\mathrm{df}_{1}$ is the degrees of freedom for the single site model and $\mathrm{df}_{2}$ the degrees of freedom for the two site model (Munson \& Rodbard, 1980; Petrash \& Bylund, 1986). A two site fit was assumed to be significantly better than a single site fit if the determined $F$ value had a $P<0.05$.

\section{Chemicals and drugs}

$\left[{ }^{3} \mathrm{H}\right]$-idazoxan $\left(40 \mathrm{Ci} \mathrm{mmol}^{-1}\right)$ was purchased from Amersham, U.K. Drugs were obtained from the following sources; noradrenaline, naphazoline, phenylephrine, clonidine and adrenaline from Sigma; cirazoline from Synthelabo; rauwolscine from Inverbeff; idazoxan from Reckitt \& Colman; UK 14304 (5 - bromo - 6 (2 -imidazolin - 2 -ylamino) - quinaxoline tartrate) from Pfizer; phentolamine from CibaGeigy; BHT 920 (6-allyl-2-amino-5,6,7,8-tetrahydro4H-thiazolo[4,5-d]azepine dihydrochloride) from Boehringer Ingelheim; WB 4101 (2-(2,6-dimethoxyphenoxyethyl)-aminomethyl-1,4-benzodioxan) from Ward Blenkinsop; cirazoline and BDF 6143 (4chloro - 2 - [2 - imidazoline - 2 - ylamino ] - isoindoline hydrochloride) were synthesized by Syntex. All other chemicals were of the highest purity commercially available.

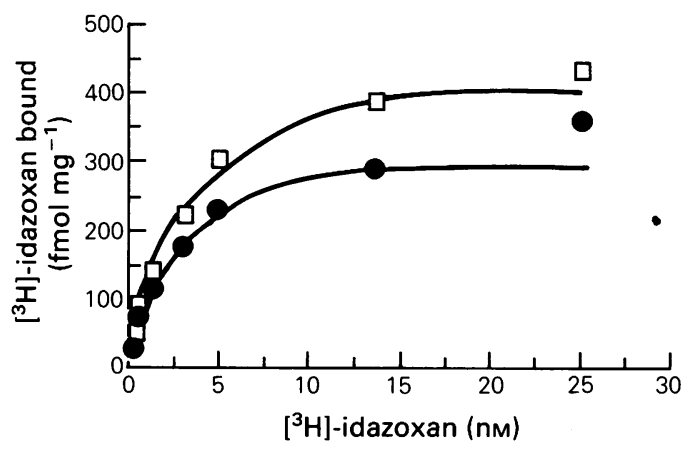

Figure $1\left[{ }^{3} \mathrm{H}\right]$-idazoxan saturation binding was carried out under control conditions $(\square) K_{\mathrm{d}} 1.7 \mathrm{nM}$, $B_{\max } 396 \mathrm{fmol} \mathrm{mg}^{-1}$ protein, or in the presence of $1 \mu \mathrm{M}$ yohimbine (O), $K_{\mathrm{d}} 2.2 \mathrm{nM}, B_{\max } 260 \mathrm{fmol} \mathrm{mg}^{-1}$ protein. The results presented are of a single experiment.

\section{Results}

The binding of $\left[{ }^{3} \mathrm{H}\right]$-idazoxan to membranes of hamster adipocytes was saturable and of high affinity (Figure 1). Iterative non-linear analysis of the binding isotherms demonstrated that $\left[{ }^{3} \mathrm{H}\right]$-idazoxan labelled a single population $\left(K_{\mathrm{d}} 2.26 \pm 0.02 \mathrm{nM}\right.$, $B_{\max } 373 \pm 25 \mathrm{fmol} \mathrm{mg}^{-1}$ protein) of binding sites (Table 1). The saturation data was also fitted to a two-site model (double rectangular hyperbola). The two-site fit was not significantly better than the onesite fit. Saturation studies were repeated in the presence of $1 \mu \mathrm{M}$ yohimbine to preclude $\left[{ }^{3} \mathrm{H}\right]$-idazoxan binding to $\alpha_{2}$-adrenoceptors (Figure 1). The number of $\left[{ }^{3} \mathrm{H}\right]$-idazoxan binding sites $\left(B_{\max }\right.$ $287 \pm 18 \mathrm{fmol} \mathrm{mg}^{-1}$ protein) was reduced, in the presence of $1 \mu \mathrm{M}$ yohimbine, without an apparent decrease in the affinity $\left(K_{d} 2.19 \pm 0.24 \mathrm{nM}\right)$ of the radioligand (Table 1 ). Thus $\alpha_{2}$-adrenoceptors only

Table $1\left[{ }^{3} \mathrm{H}\right]$-idazoxan binding to hamster adipocyte membranes

\begin{tabular}{lcc}
\hline & $\begin{array}{c}\mathrm{K}_{\mathrm{d}} \\
(\mathrm{nM})\end{array}$ & $\begin{array}{c}\mathbf{B}_{\max } \\
(\mathrm{fmol} \mathrm{mg})^{-1} \text { protein) }\end{array}$ \\
& & \\
Control & $2.26 \pm 0.02$ & $373 \pm 25$ \\
Yohimbine $(1 \mu \mathrm{M})$ & $2.19 \pm 0.24$ & $287 \pm 18^{*}$
\end{tabular}

Saturation experiments were carried out with 9 concentrations of $\left[{ }^{3} \mathrm{H}\right]$-idazoxan over the range 0.1-12 nM. In addition, saturation studies were repeated in the presence of $1 \mu \mathrm{M}$ yohimbine to preclude $\left[{ }^{3} \mathrm{H}\right]$-idazoxan binding to $\alpha_{2}$-adrenoceptors. Each value represents the mean \pm s.e.mean of three separate determinations. Statistical significance relative to control density. ${ }^{*} P<0.05$. 


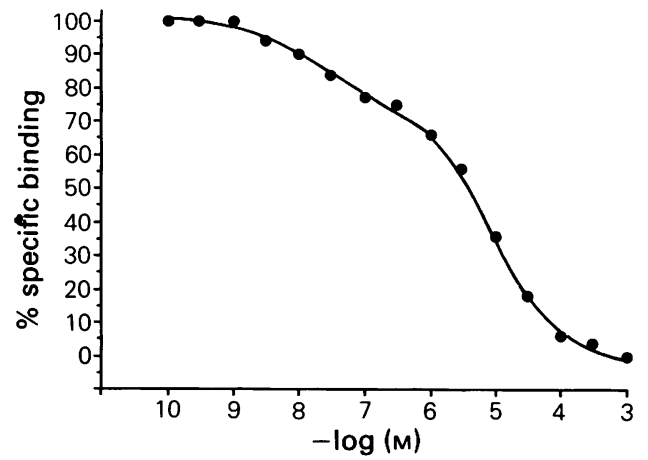

Figure 2 Displacement of $\left[{ }^{3} \mathrm{H}\right]$-idazoxan binding to hamster adipocyte membranes by phentolamine. Membranes were incubated with $1.5 \mathrm{nM}\left[{ }^{3} \mathrm{H}\right]$-idazoxan and increasing concentrations of phentolamine for $30 \mathrm{~min}$ at $25^{\circ} \mathrm{C}$. The result shown is a single experiment performed in duplicate. Computer-assisted curve fitting demonstrated that a two site fit was significantly better than a one site fit, $P<0.001$. (one site, ssmin 334010, d.f. 9; two site, ssmin 1473, d.f. 7, $F$ value 76 ).

contribute approximately $23 \%$ of the total $\left[{ }^{3} \mathrm{H}\right]$-idazoxan binding to hamster adipocytes. The failure of $1 \mu \mathrm{M}$ yohimbine to alter the $K_{\mathrm{d}}$ of $\left[{ }^{3} \mathrm{H}\right]$-idazoxan for the remaining sites implies that $\left[{ }^{3} \mathrm{H}\right]$-idazoxan has similar affinity for both the $\alpha$-adrenoceptor and the non $\alpha_{2}$-adrenoceptor site.

The displacement of $\left[{ }^{3} \mathrm{H}\right]$-idazoxan binding to adipocyte membranes by phentolamine was complex with Hill slopes considerably less than unity. Computer analysis of the displacement curves indicated that phentolamine displaced $\left[{ }^{3} \mathrm{H}\right]$-idazoxan binding with high $\left(\right.$ Site $_{1}, \mathrm{pKi}$ 7.92) and low $\left(\mathrm{Site}_{2}, \mathrm{pKi}\right.$ 5.21) affinity (Figure 2). Complex displacement curves for $\left[{ }^{3} \mathrm{H}\right]$-idazoxan binding to adipocytes were not confined to phentolamine. Noradrenaline and the $\alpha_{2}$-adrenoceptor antagonists, yohimbine, rauwolscine and BDF 6143 displaced $\left[{ }^{3} \mathrm{H}\right]$-idazoxan with low Hill slopes that could be resolved into two sites (Table 2).

We therefore compared the ability of a number of drugs with affinity for $\alpha_{2}$-adrenoceptors to displace $\left[{ }^{3} \mathrm{H}\right]$-idazoxan from site ${ }_{1}$ in hamster adipocytes and from $\alpha_{2}$-adrenoceptors in rat cerebral cortex (Table 2). The displacement of $\left[{ }^{3} \mathrm{H}\right]$-idazoxan binding by the $\alpha_{2}$-adrenoceptor antagonists was monophasic in rat cerebral cortex, with Hill slopes close to unity. The antagonist affinity rank order of BDF $6143>$ phentolamine $>$ rauwolscine $>$ yohimbine $>$ imiloxan, is consistent with $\left[{ }^{3} \mathrm{H}\right]$-idazoxan labelling an $\alpha_{2}$-adrenoceptor in rat cortex. The affinity values at the $\alpha_{2}$-adrenoceptor in rat cortex were similar to the values obtained for the displacement of $\left[{ }^{3} \mathrm{H}\right]$-idaz-
Table 2 Displacement of $\left[{ }^{3} \mathrm{H}\right]$-idazoxan binding to hamster adipocyte and rat cerebral cortical membranes

\begin{tabular}{|c|c|c|c|}
\hline & \multicolumn{3}{|c|}{$\begin{array}{r}\mathrm{pKi} \\
\text { Hamster adipocytes }\end{array}$} \\
\hline & Site $_{1}$ & Site 2 & Rat cortex \\
\hline Yohimbine & $7.28 \pm 0.02$ & $4.48 \pm 0.16$ & $7.25 \pm 0.08$ \\
\hline Rauwolscine & $7.23 \pm 0.04$ & $<4.00$ & $7.10 \pm 0.06$ \\
\hline BDF 6143 & $9.10 \pm 0.06$ & $5.92 \pm 0.04$ & $8.66 \pm 0.22$ \\
\hline Phentolamine & $7.92 \pm 0.14$ & $5.21 \pm 0.02$ & $8.33 \pm 0.21$ \\
\hline Noradrenaline & $6.21 \pm 0.10$ & $<\overline{4.00}$ & $6.70 \pm 0.13^{*}$ \\
\hline Adrenaline & $6.92 \pm 0.12$ & $<4.00$ & $7.49 \pm 0.13^{*}$ \\
\hline Imiloxan & \multicolumn{2}{|c|}{$5.67 \pm 0.08$} & $6.68 \pm 0.09$ \\
\hline Cimetidine & \multicolumn{2}{|c|}{$4.30 \pm 0.05$} & $4.53 \pm 0.07$ \\
\hline Histamine & \multicolumn{2}{|c|}{$4.78 \pm 0.07$} & $5.13 \pm 0.07$ \\
\hline
\end{tabular}

The affinity values were obtained for the displacement of specific binding of $1.5 \mathrm{~nm}\left[{ }^{3} \mathrm{H}\right]$-idazoxan from hamster adipocyte and rat cortical membranes. Site ${ }_{1}$ represents the site that displays high affinity towards the $\alpha_{2}$-adrenoceptor antagonists but only represents $20-30 \%$ of specific binding. Site $_{2}$, comprising the remaining specific binding, displays low affinity towards the $\alpha_{2}$-adrenoceptors and adrenaline and noradrenaline. Each value represents the mean \pm s.e.mean of three separate determinations. *denotes Hill slope less than unity.

oxan binding to Site $_{1}$ in adipocytes, suggesting that Site $_{1}$ represents the $\alpha_{2}$-adrenoceptor. Inhibition of $\left[{ }^{3} \mathrm{H}\right]$-idazoxan binding to hamster adipocyte membranes by the $\alpha_{2}$-adrenoceptor antagonist imiloxan, the $\alpha_{1}$-adrenoceptor antagonist prazosin and the $\mathrm{H}_{2}$-histamine receptor antagonist cimetidine were monophasic, with Hill slopes close to unity. Each drug displaced $\left[{ }^{3} \mathrm{H}\right]$-idazoxan binding with low affinity. All drugs, however were capable of displacing $100 \%$ specific binding.

The nature of the second $\left[{ }^{3} \mathrm{H}\right]$-idazoxan binding site on hamster adipocytes was examined by use of a number of $\alpha$-adrenoceptor ligands. In the presence of $1 \mu \mathrm{M}$ yohimbine to block $\left[{ }^{3} \mathrm{H}\right]$-idazoxan binding to the $\alpha_{2}$-adrenoceptor, the $\alpha$-adrenoceptor ligands with the imidazoline side chain displaced $\left[{ }^{3} \mathrm{H}\right]$-idazoxan to the remaining sites with a potency order of cirazoline > naphazoline > UK $14304>$ clonidine (Table 3). Cirazoline displaced $\left[{ }^{3} \mathrm{H}\right]$-idazoxan with a Hill slope of unity. In contrast, naphazoline, UK 14304 and clonidine displaced $\left[{ }^{3} \mathrm{H}\right]$-idazoxan binding with Hill slopes significantly different from unity. Noradrenaline and the non-imidazoline $\alpha_{2}$-adrenoceptor agonist BHT 920 failed to displace $\left[{ }^{3} \mathrm{H}\right]$-idazoxan binding from this site on hamster adipocytes. The low affinity of the $\alpha_{1}$-adrenoceptor antagonist WB 4101 and agonist phenylephrine 
Table 3 Displacement of $\left[{ }^{3} \mathbf{H}\right]$-idazoxan binding to hamster adipocytes in the presence of yohimbine $(1 \mu \mathrm{M})$

$\begin{array}{lcc} & p I C_{\text {so }} & n H \\ \text { Cirazoline } & 9.02 \pm 0.13 & 1.00 \\ \text { Naphazoline } & 7.90 \pm 0.32 & 0.50 \pm 0.08 \\ \text { UK 14304 } & 7.52 \pm 0.22 & 0.70 \pm 0.05 \\ \text { Clonidine } & 5.71 \pm 0.21 & 0.72 \pm 0.06 \\ \text { BHT 920 } & <4.00 & - \\ \text { Phenylephrine } & <4.00 & - \\ \text { WB 4101 } & <5.00 & - \\ \text { Noradrenaline } & <4.00 & -\end{array}$

Inhibition of $\left[{ }^{3} \mathrm{H}\right]$-idazoxan $(1.5 \mathrm{~nm})$ binding to hamster adipocyte membranes in the presence of yohimbine $(1 \mu \mathrm{M})$ to preclude binding to $\alpha_{2}$-adrenoceptors. Each value represents the mean \pm s.e.mean of four separate determinations.

against $\left[{ }^{3} \mathrm{H}\right]$-idazoxan binding suggests that the potency of cirazoline and naphazoline is due to their imidazoline side chain and not to an interaction with $\alpha_{1}$-adrenoceptors.

\section{Discussion}

This study indicates that $\left[{ }^{3} \mathrm{H}\right]$-idazoxan labels with high affinity two sites in hamster adipocytes; an $\alpha_{2}$-adrenoceptor and a non-adrenoceptor site. Saturation studies indicate that $\left[{ }^{3} \mathrm{H}\right]$-idazoxan hás similar affinity towards the two sites and that $\alpha_{2}$-adrenoceptors only represent a relatively small proportion of the binding of $\left[{ }^{3} \mathrm{H}\right]$-idazoxan. The results of displacement studies provide additional evidence for $\left[{ }^{3} \mathrm{H}\right]$-idazoxan binding to $\alpha_{2}$ adrenoceptors and a non-adrenoceptor site. The first binding site $\left(\right.$ Site $\left._{1}\right)$ representing approximately $20-30 \%$ of specific binding has a pharmacological profile consistent with binding to an $\alpha_{2}$-adrenoceptor. In contrast, the other site $\left(\mathrm{Site}_{2}\right)$ representing $70-80 \%$ specific binding, is unlikely to be an $\alpha_{2}$-adrenoceptor since the antagonists yohimbine, rauwolscine, and BDF 6143 failed to displace $\left[{ }^{3} \mathrm{H}\right]$-idazoxan binding at pharmacologically relevant concentrations. Furthermore, the low affinity of noradrenaline and adrenaline towards this binding site makes it unlikely that it is an adrenoceptor.

Competition experiments indicate that compounds containing the imidazoline side chain are potent displacers of $\left[{ }^{3} \mathrm{H}\right]$-idazoxan binding to $\mathrm{Site}_{2}$ in adipocytes. The rank order potency of: $\alpha_{1}$-adrenoceptor agonists, (cirazoline and naphazoline) $>$ the imidazoline $\alpha_{2}$-adrenoceptor agonists, UK 14304 > clon- idine $>$ the non-imidazoline $\alpha_{2}$-adrenoceptor agonist, BHT 920 is consistent with $\left[{ }^{3} \mathrm{H}\right]$-idazoxan labelling an imidazoline site. The failure of the $\alpha_{1}$-adrenoceptor agonist phenylephrine and the antagonist WB 4101 to displace $\left[{ }^{3} \mathrm{H}\right]$-idazoxan from $\mathrm{Site}_{2}$ in adipocytes, suggests that the high affinity of cirazoline and naphazoline is due to the imidazoline side chain and not to an interaction at $\alpha_{1}$-adrenoceptors. Cirazoline has been reported to display higher affinity towards $\left[{ }^{3} \mathrm{H}\right]$-clonidine binding than $\left[{ }^{3} \mathrm{H}\right]$-prazosin binding to rat brain (Van Meel et al., 1981). In field stimulated guinea-pig ileum, cirazoline competitively antagonized the $\alpha_{2}$-adrenoceptor mediated inhibition of twitch height with a $\mathrm{pA}_{2}$ of 7.56 (Ruffolo \& Waddell, 1982). Thus cirazoline can act as an $\alpha_{1}$-adrenoceptor agonist and an $\alpha_{2}$-adrenoceptor antagonist. The finding of this study that cirazoline displaces $\left[{ }^{3} \mathrm{H}\right]$-idazoxan binding, in the presence of yohimbine, with high affinity indicates that this compound also binds to the imidazoline site in hamster adipocytes.

Imidazoline binding sites, labelled by $\left[{ }^{3} \mathrm{H}\right]$ idazoxan, have been described previously. The imidazoline related compounds, cirazoline and UK 14304 displace $\left[{ }^{3} \mathrm{H}\right]$-idazoxan from rabbit urethral membranes with high affinity, whereas yohimbine, rauwolscine and the phenylethanolamines, adrenaline, noradrenaline and $\alpha$-methyl- $( \pm)$-noradrenaline are essentially devoid of affinity (Yablonsky et al., 1988). Imidazoline binding sites have been identified in rabbit cerebral cortex and kidney (Coupry et al., 1987; Hamilton et al., 1988) and rabbit adipocytes (Langin \& Lafontan, 1989). The affinity rank order of cirazoline (pKi 8.50) > naphazoline (pKi 8.3) UK 14304 (pKi 6.52) > clonidine (pKi 5.90) for the displacement of $\left[{ }^{3} \mathrm{H}\right]$-idazoxan from rabbit urethral membranes is in agreement, with the exception of UK 14304, with the values obtained in this study. The affinities reported by Langin \& Lafontan (1989) for naphazoline (pKi 8.00) and clonidine (pKi 6.01) suggests that the imidazoline binding site in hamster adipocytes is likely to be similar to the one that exists in rabbit adipocytes. However, the affinity of UK 14304 in both rabbit urethral membranes and adipocytes (pKi 6.02) is less than its affinity (pKi 7.52) for the imidazoline site in hamster adipocytes. In both rabbit urethral and adipocyte membranes, the affinity of idazoxan was higher at the imidazoline binding site than at the $\alpha_{2}$-adrenoceptor in the corresponding tissue. This contrasts with the findings of this study in which $\left[{ }^{3} \mathrm{H}\right]$-idazoxan has a similar affinity at the $\alpha_{2}$-adrenoceptor and the imidazoline binding site. Whether this represents a species difference between the imidazoline sites or a difference in sensitivity of $\left[{ }^{3} \mathrm{H}\right]$-idazoxan and UK 14304 in the different buffer systems used has still to be resolved. The $\alpha_{2}$-adrenoceptor agonist, $p$-aminoclonidine 
binds to two sites in bovine ventrolateral medulla: an $\alpha_{2}$-adrenoceptor and a non-adrenoceptor site, insensitive to catecholamines (Meeley et al., 1986; Ernsberger et al., 1987). This second site has also been identified in human brainstem (Bricca et al., 1988) where it is labelled by $\left[{ }^{3} \mathrm{H}\right]$-clonidine (Bricca et al., 1989). In displacement studies, cirazoline displaced $\left[{ }^{3} \mathrm{H}\right]$-clonidine with high affinity whereas $\mu$ molar concentrations of yohimbine were required to induce the same effect. At present, insufficient evidence is available to determine whether the nonadrenoceptor $\left[{ }^{3} \mathrm{H}\right]$-clonidine binding site in human brainstem is identical with the non-adrenoceptor $\left[{ }^{3} \mathrm{H}\right]$-idazoxan binding site on hamster adipocytes. The low affinity of clonidine towards the nonadrenoceptor site on hamster adipocytes would argue against these sites being similar.

The displacement of $\left[{ }^{3} \mathrm{H}\right]$-idazoxan binding to Site $_{2}$ in adipocyte membranes is apparently selective for the imidazoline structure. Imiloxan, an imidazole $\alpha_{2}$-adrenoceptor antagonist was considerably less potent in displacing $\left[{ }^{3} \mathrm{H}\right]$-idazoxan from this site in hamster adipocytes than at the $\alpha_{2}$-adrenoceptor in rat brain. Imidazole binding sites have also been described. Displacement of the binding of the imidazole $\mathrm{H}_{2}$-histamine receptor antagonist $\left[{ }^{3} \mathrm{H}\right]$-cimetidine to membranes of cerebral cortical and medulla pons indicated that this ligand was not binding to an $\mathrm{H}_{2}$-receptor but to an imidazole site (Rising et al., 1980; Subramanian \& Slotkin, 1981). Clonidine and phentolamine potently inhibited $\left[{ }^{3} \mathrm{H}\right]$-cimetidine binding to the imidazole site in rat brain (Burkard, 1978; Subramanian \& Slotkin, 1981). In this study, the imidazoles histamine and cimetidine although displacing $\left[{ }^{3} \mathrm{H}\right]$-idazoxan binding completely, were only of low potency.

$\left[{ }^{3} \mathrm{H}\right]$-idazoxan is used frequently as a radioligand to label $\alpha_{2}$-adrenoceptors in both central and peripheral tissue. A recent autoradiographical and binding study carried out in a sodium phosphate buffer, suggests that $\left[{ }^{3} \mathrm{H}\right]$-idazoxan labels a heter- ogeneous population of binding sites in rat brain and that one population of these sites is selectively labelled by $\left[{ }^{3} \mathrm{H}\right]$-raulwolscine (Boyajian et al., 1987; Boyajian \& Leslie, 1987). There were approximately 4 times the number of 'idazoxan' sites as for rauwolscine. A possible explanation for the apparent discrepancy between the density of sites identified by the two radioligands is that $\left[{ }^{3} \mathrm{H}\right]$-idazoxan labels an imidazoline binding site in addition to $\alpha_{2}$-adrenoceptors. $\left[{ }^{3} \mathrm{H}\right]$-idazoxan binding to rat cortical membranes was carried out in this study under conditions that define $\alpha_{2}$-adrenoceptors. The existence of imidazoline binding sites in rat cortex, must await specifically designed studies.

Evidence from studies on isolated adipocytes suggest that it is the $\alpha_{2}$-adrenoceptor that is responsible for modifying $\alpha$-adrenergic stimulation of lipolysis in human (Berlan \& Lafontan, 1982), rat (Sundin \& Fain, 1983) and hamster adipocytes (Carpene et al., 1980). Cirazoline, a compound shown in this study to possess high affinity for the imidazoline binding site on hamster adipocytes, had no effect on noradrenaline- or isoprenalinestimulated lipolysis, at concentrations up to $1 \times 10^{-5} \mathrm{M}$ (Curtis-Prior \& Tan, 1983). Under identical conditions, a concentration-dependent inhibition of lipolysis was observed with clonidine. Thus at present the functional significance of the imidazoline binding site in hamster adipocytes remains uncertain.

These results provide additional evidence that $\left[{ }^{3} \mathrm{H}\right]$-idazoxan labels in addition to $\alpha_{2}$-adrenoceptors, a non-adrenoceptor imidazoline site in hamster adipocytes that is similar to the site recently described in rabbit adipocytes (Langin \& Lafontan, 1989). The hamster adipocyte may provide a useful test system for exploring the relationship between $\alpha_{2}$-adrenoceptors and imidazoline binding sites.

We thank Dr R. Clark for the synthesis of BDF 6143.

\section{References}

BERLAN, M. \& DANG TRAN, L. (1978). Intervention de recepteurs adrenergiques alpha et beta dans l'effet des catecholamines sur la lipolyse d'adipocytes de chien. $J$. Physiol, (Paris), 74, 601-608.

BERLAN, M. \& LAFONTAN, M. (1980). Identification of $\alpha_{2}$-adrenergic receptors in human fat cell membranes by $\left[{ }^{3} \mathrm{H}\right]$ clonidine binding. Eur. J. Pharmacol., 67, 481-484.

BERLAN, M. \& LAFONTAN, M. (1982). The $\alpha_{2}$-adrenergic receptor on human fat cells: comparative study of $\alpha_{2}$-adrenergic radioligand binding and biological response. J. Physiol. (Paris), 78, 279-287.

BOYAJIAN, C.L., LOUGHLIN, S.E. \& LESLIE, F.M. (1987). Anatomical evidence for alpha-2 adrenoceptor heter- ogeneity: differential autoradiographic distribution of $\left[{ }^{3} \mathrm{H}\right]$ rauwolscine and $\left[{ }^{3} \mathrm{H}\right]$ idazoxan in rat brain. $J$. Pharmacol. Exp. Ther., 241, 1079-1091.

BOYAJIAN, C.L. \& LESLIE, F.M. (1987). Pharmacological evidence for alpha-2 adrenoceptor heterogeneity: differential binding properties of $\left[{ }^{3} \mathrm{H}\right]$ rauwolscine and $\left[{ }^{3} \mathrm{H}\right]$ idazoxan in rat brain. J. Pharmacol. Exp. Ther., 241, 1092-1098.

BRICCA, G., DONTENWILL, M., MOLINES, A., FELDMAN, J., BELCOURT, A. \& BOUSQUET, P. (1988). Evidence for the existence of a homogeneous population of imidazoline receptors in the human brainstem. Eur. J. Pharmacol., 150, 401-402. 
BRICCA, G., DONTENWILL, M., MOLINES, A., FELDMAN, J., BELCOURT, A. \& BOUSQUET, P. (1989). The imidazoline preferring receptor: binding studies in bovine, rat and human brainstem. Eur. J. Pharmacol., 162, 1-19.

BURKARD, W.P. (1978). Histamine $\mathrm{H}_{2}$-receptor binding with ${ }^{3} \mathrm{H}$-cimetidine in brain. Eur. J. Pharmacol., 50, 449-450.

BURNS, T.W., LANGLEY, P.E. \& ROBISON, G.A. (1971). Adrenergic receptors and cyclic AMP in the regulation of human adipose tissue lipolysis. Ann. N.Y. Acad. Sci., 185, 115-128.

CARPENE, C., LAFONTAN, M. \& BERLAN, M. (1980). A postsynaptic alpha ${ }_{2}$-receptor: the alpha-adrenergic receptor of hamster fat cells. Experientia, 36, 1413-1414.

CHAPLEO, C.B., DOXEY, J.C., MYERS, P.L. \& ROACH, A.G. (1981). RX781094, a new potent, selective antagonist of $\alpha_{2}$-adrenoceptors. Br. J. Pharmacol., 74, 824P.

CHENG, Y.C. \& PRUSOFF, W.H. (1973). Relationship between the inhibition constant $(\mathrm{Ki})$ and the concentration of inhibitor which caused 50 per cent inhibition $\left(\mathrm{I}_{\text {so }}\right)$ of an enzymic reaction. Biochem. Pharmacol., 22, 3099-3108.

COUPRY, I., PODEVIN, R.A., DAUSSE, J.P. \& PARINI, A. (1987). Evidence for imidazoline binding sites in basolateral membranes from rabbit kidney. Biochem. Biophys. Res. Commun., 147, 1055-1060.

CURTIS-PRIOR, P.B. \& TAN, S. (1983). Regulation of adipose tissue metabolism via adrenergic mechanisms: action of alpha-adrenergic agonists on lipolysis in hamster fat cells. Int. J. Obes., 7, 299-305.

CURTIS-PRIOR, P.B. \& TAN, S. (1984). Application of agents active at the alpha 2-adrenoceptor of fat cells to the treatment of obesity - a critical appraisal. Int. J. Obes., 8, 201-213.

ERNSBERGER, P., MEELEY, M.P., MANN, J.J. \& REIS, D.J. (1987). Clonidine binds to imidazole binding site as well as $\alpha_{2}$-adrenoceptors in the ventrolateral medulla. Eur. $J$. Pharmacol., 134, 1-13.

FAIN, J.N. \& GARCIA-SAINZ, J.A. (1983). Adrenergic regulation of adipocyte metabolism. J. Lipid Res., 24, 949-966.

GARCIÁ-SAINZ, J.A., HOFFMAN, B.B., LI, S.Y., LEFKOWITZ, R.J. \& FAIN, J.N. (1980). Role of alpha ${ }_{1}$-adrenoceptors in the turnover of phosphatidyl-inositol and of alpha ${ }_{2}$ adrenoceptors in the regulation of cyclic AMP accumulation in hamster adipocytes. Life Sci., 27, 953-961.

GIUDICELli, Y., PECQUERY, R., PROVIN, D., AGLI, B. \& NORDMANN, R. (1977). Regulation of lipolysis and cyclic AMP synthesis through energy supply in isolated human fat cells. Biochem. Biophys. Acta., 486, 385-398.

HAMILTON, C.A., REID, J.L. \& YAKUBA, M.A. (1988). $\left[{ }^{3} \mathrm{H}\right]$ yohimbine and $\left[{ }^{3} \mathrm{H}\right]$ idazoxan bind to different sites on rabbit forebrain and kidney membranes. Eur. $J$. Pharmacol., 146, 345-348.

HITTELMAN, K.J., WU, C.F. \& BUTCHER, R.W. (1973). Control of cyclic AMP levels in isolated fat cells from hamsters. Biochim. Biophys. Acta., 304, 188-196.

HUERTA-BAHENA, J., VILLALOBOS-MOLINA, R. \& GARCIA-SAINZ, J.A. (1983). Trifluoperazine and chlorpromazine antagonize alpha 1- but not alpha 2adrenergic effects. Mol. Pharmacol., 23, 67-70.

LAFONTAN, M. \& BERLAN, M. (1980). Evidence for the $\alpha_{2}$ nature of the $\alpha$-adrenergic receptor inhibiting lipolysis in human fat cells. Eur. J. Pharmacol., 66, 87-93.
LAFONTAN, M., BERLAN, M. \& VILLENEUVE, A. (1983). Preponderance of alpha $a_{2}$ - over beta ${ }_{1}$-adrenergic receptor sites in human fat cells is not predictive of the lipolytic effects of physiological catecholamines. J. Lipid Res., 24, 429-440.

LAFONTAN, M., BERLAN, M. \& CARPENE, C. (1985). Fat cell adrenoceptors: inter- and intraspecific differences and hormone regulation. Int. J. Obes., 1, 117-127.

LANGIN, D. \& LAFONTAN, M. (1989). [ ${ }^{3}$ H]Idazoxan binding at non- $\alpha_{2}$-adrenoceptors in rabbit adipocyte membranes. Eur. J. Pharmacol., 159, 199-203.

LOWRY, O., ROSEBROUGH, N., FARR, A. \& RANDALL, J. (1951). Protein measurement with the Folin phenol reagent. J. Biol. Chem., 193, 265-275.

MEELEY, M.P., ERNSBERGER, P.R., GRANATA, A.R. \& REIS, D.J. (1986). An endogenous clonidine-displacing substance from the bovine brain: receptor binding and hypotensive actions in the ventrolateral medulla. Life Sci., 38, 1119-1126.

MUNSON, P.J. \& RODBARD, D. (1980). LIGAND: a versatile computerized approach for characterization of ligand-binding systems. Analyt. Biochem., 107, 220-239.

PECQUERY, R. \& GIUDICELLI, Y. (1980). Heterogeneity and subcellular localization of hamster adipocyteadrenergic receptors. Evidence of $\alpha_{1}$ - and $\alpha_{2}$-subtypes. FEBS Lett., 116, 85-90.

PETRASH, A.C. \& BYLUND, D.B. (1986). Alpha-2 adrenergic receptor subtypes indicated by $\left[{ }^{3} \mathbf{H}\right]$-yohimbine binding in human brain. Life Sci., 38, 2129-2137.

RICHELSEN, B. \& PEDERSEN, O. (1985). $\alpha_{2}$-Adrenergic binding and action in human adipocytes. Comparison between binding to plasma membrane preparations and to intact adipocytes. Eur. J. Pharmacol., 119, 101-112.

RISING, T.J., NORRIS, D.B., WARRANDDER, S.E. \& WOO, T.P. (1980). High affinity $\left[{ }^{3} \mathrm{H}\right]$ cimetidine binding in guinea-pig tissues. Life Sci., 27, 199-206.

RODBELL, M. (1964). Metabolism of isolated fat cells. $J$. Biol. Chem., 239, 375-378.

RUFFOLO, R.R. \& WADDELL, J.E. (1982). Receptor interactions of imidazolines. IX. Cirazoline is an alpha-1 adrenergic agonist and an alpha-2 adrenergic antagonist. J. Pharmacol. Exp. Ther., 222, 29-36.

SUBRAMANIAN, N. \& SLOTKIN, T.A. (1981). Solubilization of a $\left[{ }^{3} \mathrm{H}\right]$ cimetidine binding site from rat brain: a clonidine-sensitive H-2 receptor subtype? Mol. Pharmacol., 20, 240-243.

SUNDIN, U. \& FAIN, J.N. (1983). Alpha 2-adrenergic inhibition of lipolysis and respiration in rat brown adipocytes. Biochem. Pharmacol., 32, 3117-3120.

TAN, S. \& CURTIS-PRIOR, P.B. (1983). Prostaglandins, alpha-adrenergic receptors and lipolysis in hamster fat cells. Prostaglandins Leukotrienes Med., 17, 117-123.

TAN, S. \& CURTIS-PRIOR, P.B. (1984). Comparative effects of RX 781094, mianserin, yohimbine, rauwolscine and prazosin in reversing clonidine inhibition of MIXstimulated lipolysis in hamster isolated white fat cells. Pharmacol. Res. Commun., 16, 461-466.

THARP, M.D., HOFFMAN, B.B. \& LEFKOWITZ, R.J. (1981). $\alpha$-Adrenergic receptors in human adipocyte membranes: Direct determination by $\left[{ }^{3} \mathrm{H}\right]$ yohimbine binding. $J$. Clin. Endocrinol. Metab., 52, 709-714.

TAOUIS, M., BERLAN, M. \& LAFONTAN, M. (1986). $\alpha_{2}$-Adrenergic receptor turnover in adipose tissue and 
kidney: irreversible blockade of $\alpha$-adrenergic receptors by benextramine. Mol. Pharmacol., 31, 89-96.

VAN MEEL, J.C.A., DEJONG, A., TIMMERMANS, P.B.M.W.M. \& VAN ZWIETEN, P.A. (1981). Selectivity of some alpha adrenoceptor agonists for peripheral alpha- 1 and alpha-2 adrenoceptors in the normotensive rat. $J$. Pharmacol. Exp. Ther., 219, 760-767.

VILLENEUVE, A., CARPENE, C., BERLAN, M. \& LAFONTAN, M. (1985). Lack of desensitization of alpha-2-mediated inhibition of lipolysis in fat cells after acute and chronic treatment with clonidine. J. Pharmacol. Exp. Ther., 233, 433-440.

YABLONSKY, F., RIFFAUD, J.P., LACOLLE, J.Y. \& DAUSSE, J.P. (1988). Evidence for non-adrenergic binding sites for $\left[{ }^{3} \mathbf{H}\right]$ idazoxan in the smooth muscle of rabbit urethra. Eur. J. Pharmacol., 154, 209-212.

(Received February 9, 1989

Revised July 25, 1989

Accepted July 31, 1989) 